\title{
A REVIEW ON THE COVID-19 (NOVEL CORONAVIRUS) - CHARACTERISTICS, EVALUATION, AND TREATMENT
}

\author{
Devendra Kumar Mishra \\ Amity Institute of Pharmacy, \\ Amity University, Uttar Pradesh Lucknow Campus, \\ Lucknow, Uttar Pradesh, India
}

\begin{abstract}
In December 2019, there was a flare-up of the unidentified reason for pneumonia that overwhelmed the vast majority of the world. This infection has a place with $\beta$-coronavirus, an enormous class of infections common in nature. On the 11th of February 2020, W.H.O named this disease as COVID-19 (Coronavirus Disease 2019). This novel coronavirus is to be believed to get spread from the bat and later on a human to human transmission. These patients gave indications of extreme pneumonia including fever, weakness, dry cough and respiratory trouble. Still, the exact mechanism of its approach has not been cleared yet. But it's said to be the same as the previous strain of it like SARS-CoV and MERS-CoV. It has been affirmed that the COVID-19 also uses the cell section receptor i.e.; ACE2 as the SARS-CoV. The COVID-19 said to transmit starting with one then onto the next individual, so it is important to totally intrude on human-to-human transmission. Another method to control the spread is to avoid the diligence of coronaviruses on inanimate surfaces because of various kinds of materials it can stay irresistible for 2 hours as long as 9 days. The typical standards are keeping up hydration and sustenance and controlling fever and cough. The typical standards are keeping up hydration and sustenance and controlling fever and cough. But still, the previously used antiviral drugs as well as like antibody and convalescent plasma as a potential therapy were used in the treatment.
\end{abstract}

Keywords - Coronavirus, RT-qPCR, COVID-19, pneumonia, SARS-CoV-2.

\section{INTRODUCTION}

Coronaviruses cause ailment going in seriousness from the regular cold to extreme respiratory disease and death. In

\author{
Dr.Himani Awasthi \\ Amity Institute of Pharmacy, \\ Amity University, Uttar Pradesh Lucknow Campus, \\ Lucknow, Uttar Pradesh, India
}

December 2019, there was a flare-up of the unidentified reason for pneumonia that overwhelmed the vast majority of the world. The COVID-19 (Coronavirus virus 2019) as it is presently called was blasted out from the city of Wuhan, of the People's Republic of China, which raised serious consideration inside China as well as globally. ${ }^{[1]}$ Till 20/05/2020 around 5,002,458 instances of COVID-19 and 325,214 deaths have been accounted for around the world, and India has revealed 106,886 cases to date. ${ }^{[2]}$ This infection has a place with $\beta$ coronavirus, an enormous class of infections common in nature. Like different infections, severe acute respiratory syndrome coronavirus 2 (SARS-CoV-2) has numerous potent common moderator, middle moderator, and last moderator. These stances incredible difficulty in counteraction and treatment of infectious disease contrasted with Severe Acute Respiratory syndrome-Coronavirus (SARS-CoV) and MiddleEast Respiratory Syndrome-Coronavirus (MERS-CoV), this infection has extremely spreadable. ${ }^{[3]}$

\section{HISTORY}

Novel coronavirus was believed to be having zero patients from the "seafood market" in Wuhan. This novel coronavirus is to be believed to get spread from the bat and later on a human to human transmission. ${ }^{[5]}$ Coronaviruses are inserted with precision RNA viruses ranging from $60 \mathrm{~nm}$ to $140 \mathrm{~nm}$ away from a spike-like guessing surface that gives them a crown-like appearance under an electron magnification lens. ${ }^{[6]}$ On January 30, 2020, the World Health Organization (W.H.O) declared the outbreak a Public Health Emergency of International Concern (PHEIC). ${ }^{[7]}$ On the $11^{\text {th }}$ of February 2020, W.H.O named this disease as COVID-19 (Coronavirus Disease 2019). ${ }^{[8]}$ 


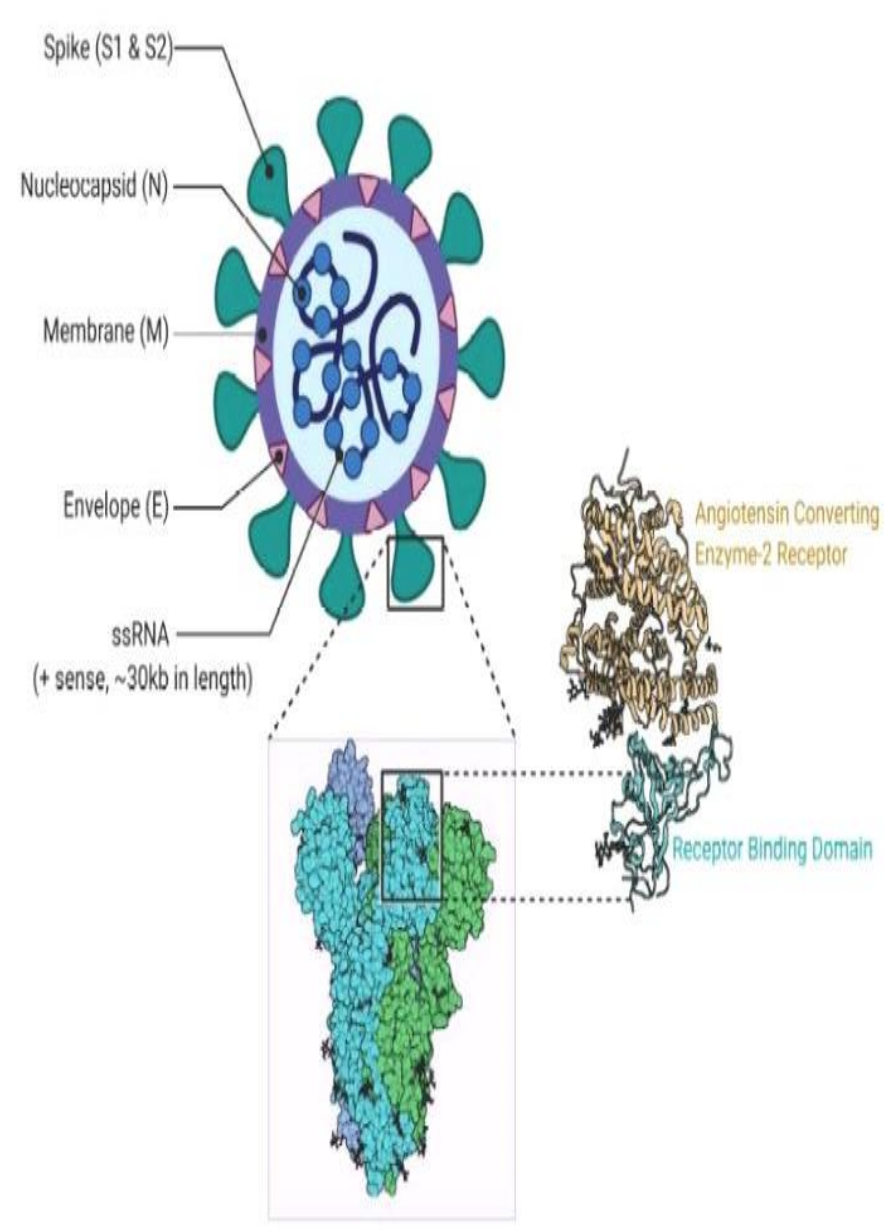

Fig 1. SARS-CoV 2 Structure ${ }^{[9]}$

\section{ETIOLOGY}

Viral genome investigation uncovers that the virus contains the almost $88 \%$ similarity with two bats which were involved in the SARS, however increasingly far off from SARS-CoV. [10] Thus, it was called the COVID-19. CoVs are certain stranded RNA virus that is coated with a crown-shaped visual under an electron magnifying instrument (coronam is the Latin expression for crown) because of the nearness of spike glycoproteins on the envelope. [11] There are majorly four auxiliary proteins that are attached by the coronaviral genome on the envelope, thus there is a spike (S) on which the angiotensin-converting enzyme-2 (ACE-2) receptor get bind and mediates the consequent combination between the envelope and moderator cell layers to facilitate viral transfer to the moderator cell. ${ }^{[12]}$

Individuals from this enormous group of viruses can cause respiratory, enteric, hepatic, and neurological disorders in various species, including camels, cattle, cats, and bats. ${ }^{[13]}$

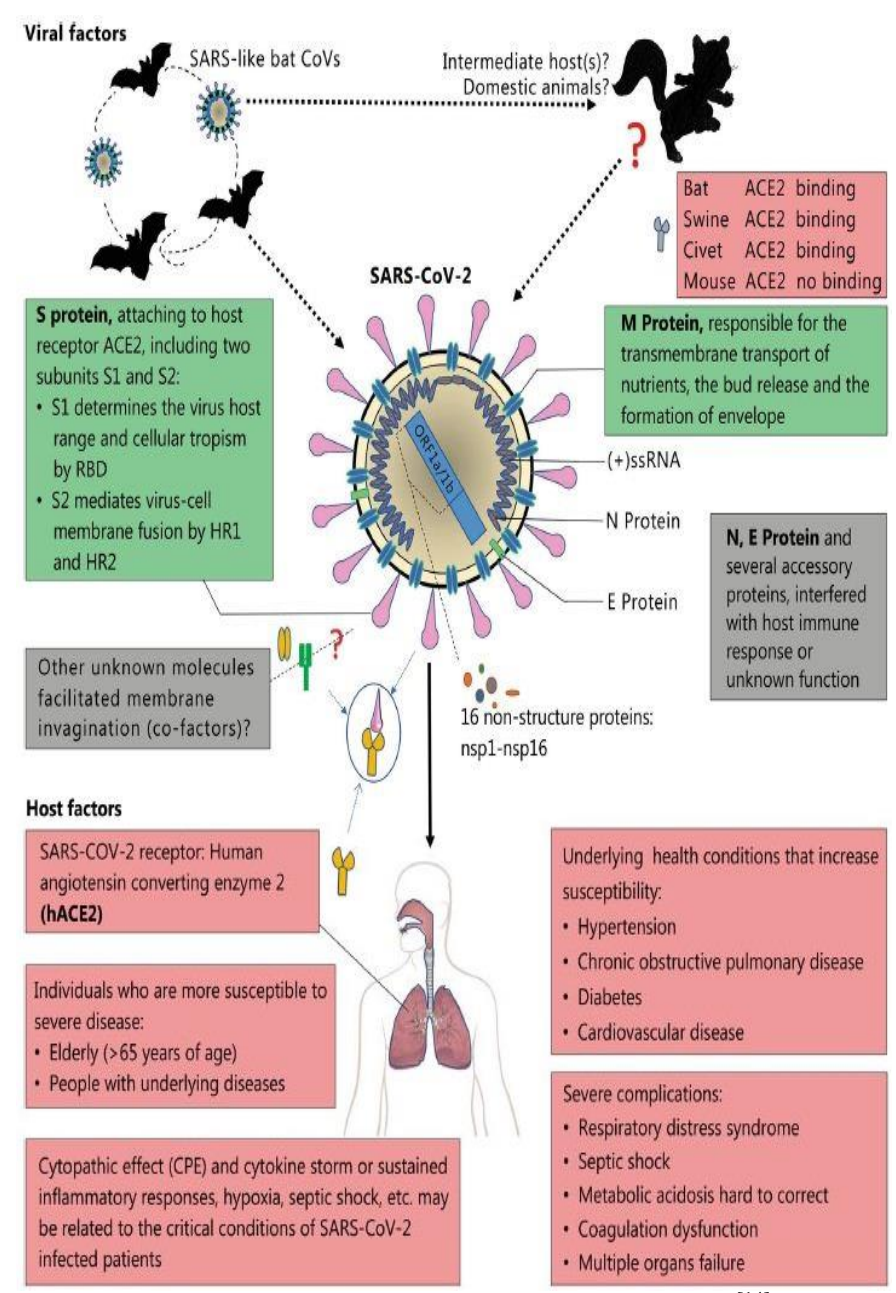

Fig 2. The Clinical approach of COVID-19 ${ }^{[14]}$

\section{SYMTOMS}

COVID-19 syndrome shows up after a hatching time of roughly 5-6 days. ${ }^{[15]}$ The time from the onset of COVID-19 symptoms starts till the death ranges from 6 to 41 days and it has the midpoint or said to be the peal at around 14 days. This period may be different according to the age and the immunity of the patient which can unmatch the frame of time. ${ }^{[16]}$ These patients gave indications of extreme pneumonia including fever, weakness, dry cough and respiratory trouble. ${ }^{[12]}$

Clinical highlights uncovered the major issue as pneumonia with the help of a CT scan of the chest. However, there are numerous abnormalities such as sore throat, intense respiratory pain disorder, and hypoxemia. Also, it causes intense injury of cardiovascular, ground-glass opacities, sneezing, and RNAaemia which leads to death. ${ }^{[17]}$ Critically, though patients contaminated with COVID-19 face the adverse gastrointestinal effects such as diarrhea, there are very fewer patients of SARS-CoV or MERS-CoV who also face the same effect as like the COVID-19. Hence, it should be clear that the fecal and urine must be examined to avoid any other cause of transmission. ${ }^{[18]}$ 


\section{International Journal of Engineering Applied Sciences and Technology, 2020 \\ Vol. 5, Issue 1, ISSN No. 2455-2143, Pages 215-221 \\ Published Online May 2020 in IJEAST (http://www.ijeast.com)}

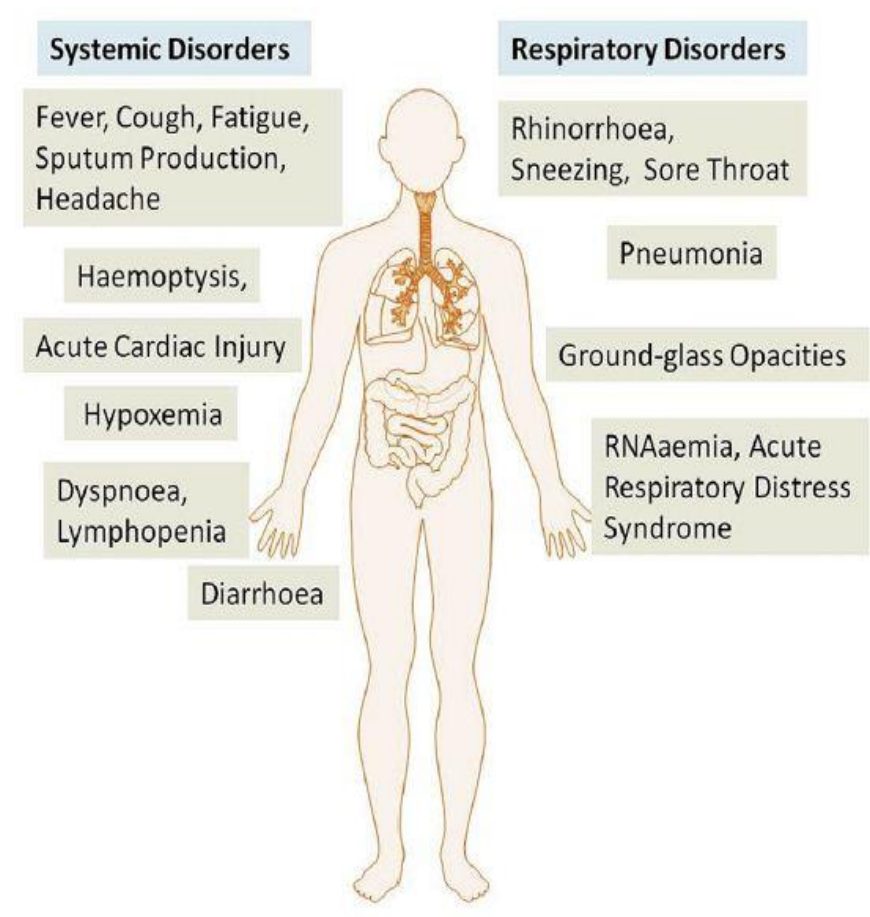

Fig 3. Clinical presentation of patients with COVID-19 [19]

\section{TRANSMISSION}

Endeavors have been made to determine the supply modulator or halfway transporters from which the contamination may have got to people. ${ }^{[20]}$ There are various reports which stated that the prime transmission of the COVID-19 is the interaction between the individual to individual. [21] Individual-toindividual transmission happens principally employing when the infected person came directly in touch with the noninfected person or when the infected person cough or sneeze then the droplets are leads to the transmission.

There are also some reports which stated that, if a mother is suffering from the coronavirus but still there are no records of transmission in their child from its mother. In any case, every single pregnant mother experienced cesarean segments, so it remains unclear whether the transfer happens during vaginal birth. It is significant on the grounds that pregnant moms are generally increasingly major targets to get exposed to infection by respiratory tract infections and as well as serious pneumonia. ${ }^{[22]}$

The receptor-mediated cells are the first step in viral infection followed by cell and cell adhesion. The first and most prime target for the virus is an aid to be epithelial cells of lungs which prove the virus. In this manner, the ACE2 receptor has been recognized as which is responsible for the intermediate domain that binds virus spikes with the cell receptor which cause by the human-to-human transmission of SARS-CoV. [23] This information unequivocally recommends that section into the modulator cells is all possible via the ACE2 receptor. ${ }^{24]}$

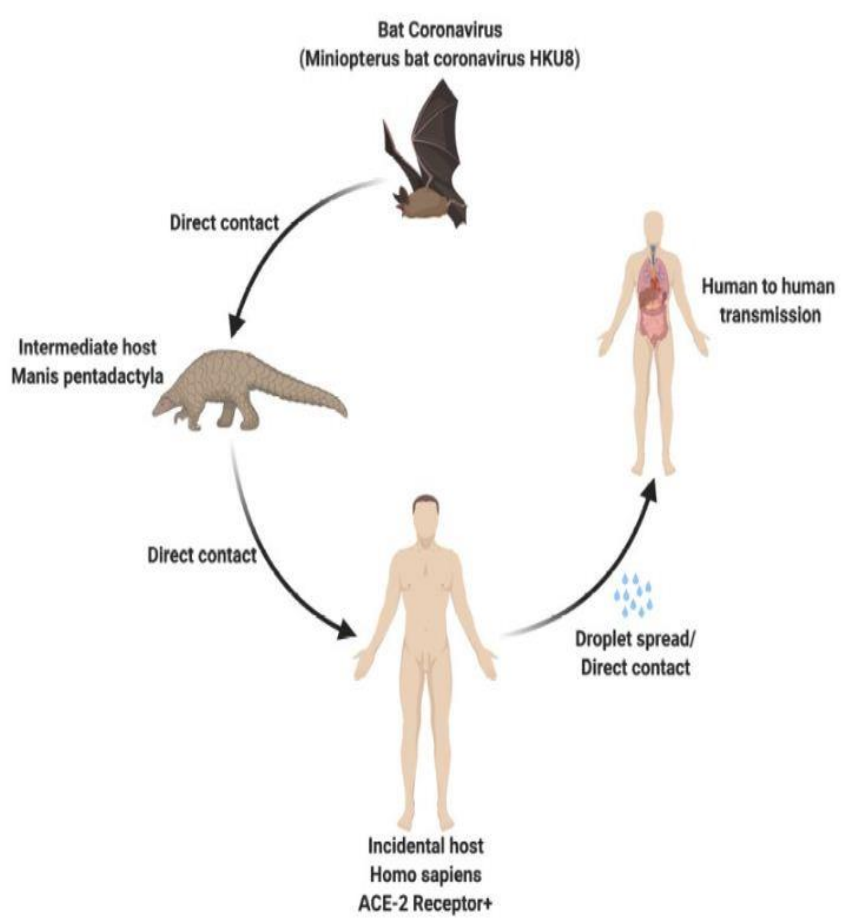

Fig 4. Transmission of COVID-19 infection [9]

\section{PATHOPHYSIOLOGY}

Still, the exact mechanism of its approach has not been cleared yet. But it's said to be the same as the previous strain of it like SARS-CoV and MERS-CoV, which gives a creditable approach of its mechanism to identify the pathway of the COVID-19. ${ }^{[25]}$ ACE2 is identified as the cell receptor of the SARS-CoV that is present at the lower respiratory tract of humans ${ }^{[26]}$ and it helps in the regulation of both transient organisms and also in the transmission of individual-toindividual. ${ }^{[24]}$ It has been affirmed that the COVID-19 also uses the cell section receptor i.e.; ACE2 as the SARS-CoV follows when the sample was isolated from the bronchoalveolar lavage fluid (BALF) of the patients. ${ }^{\text {[27] }}$ The report revealed that the virion $\mathrm{S}$-glycoprotein interacts with the receptor from outside of the coronavirus, whereas the interaction of ACE2 generally occurred from the outside of the human cells. ${ }^{[28]}$ The discharge of the viral genome RNA into the cytoplasm occurred after membrane combination, and then it initiates the unregistered RNA translates into two polyproteins, which is knowns the ppla and pplab ${ }^{[29]}$, which helps in twofold layer vesicle through concealing of and structure RTC (replication-transcription complex) and nonauxiliary proteins. ${ }^{[30]}$ Consistently, a structured arrangement of subgenomic RNAs were incorporated by the return of the

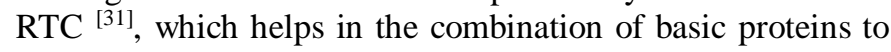
protein coupling. Intervening of the Golgi complex and the endoplasmic reticulum (ER) ${ }^{[32]}$, and the structure of viral molecule buds was done collecting the recent shaped envelope of the glycoproteins, nucleocapsid proteins, and genomic 


\section{International Journal of Engineering Applied Sciences and Technology, 2020 \\ Vol. 5, Issue 1, ISSN No. 2455-2143, Pages 215-221 \\ Published Online May 2020 in IJEAST (http://www.ijeast.com)}

RNA. Finally, the viruses get a discharge with the help of a plasma layer by the intertwining of vesicles containing the virion. Since the approval of the SARS-CoV-2 Spike (S) glycoprotein and ACE2 receptor is the beginning of the viral phase, virus-receptor restriction is under intense investigation through various mechanisms. ${ }^{[33]}$

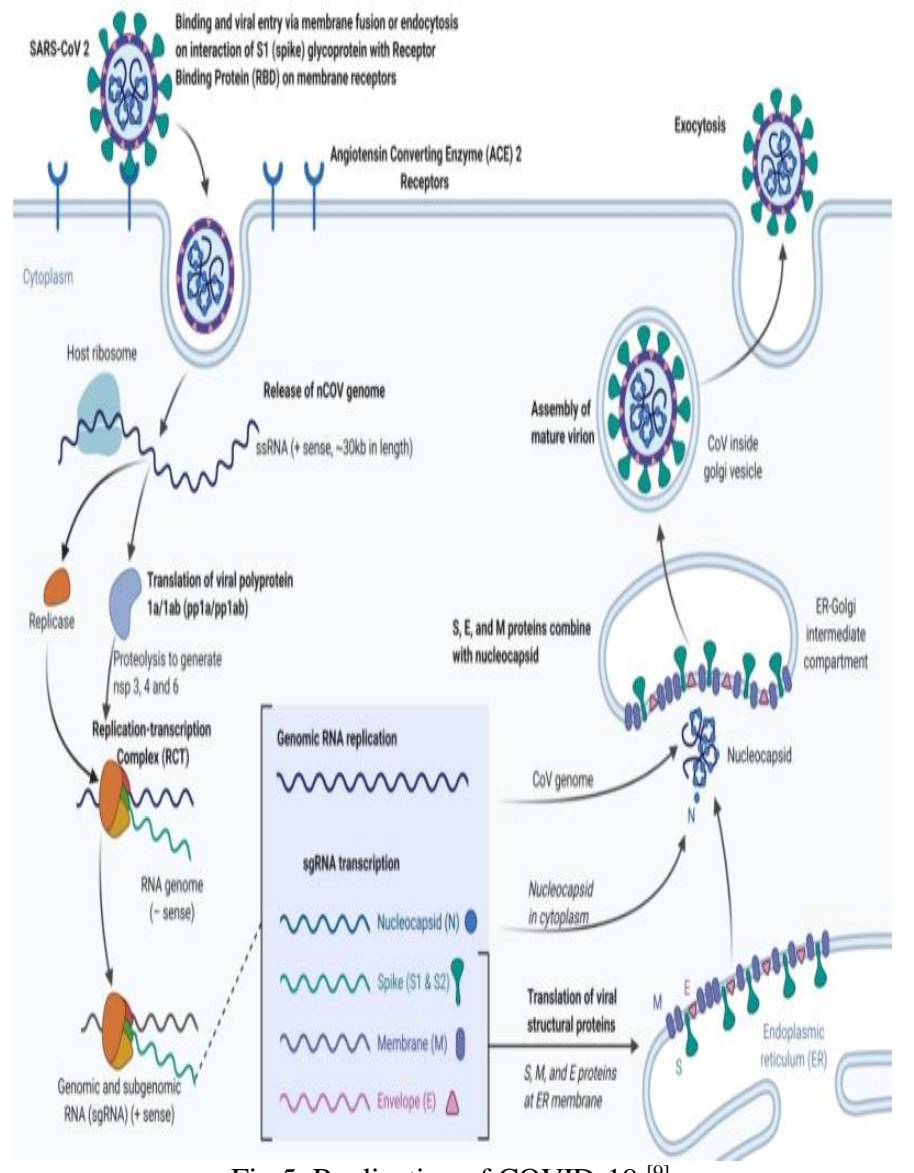

Fig 5. Replication of COVID-19 [9]

\section{EvaluATION}

The initiation of a viral study in China has led primer distinguishing proof of SARS-CoV-2 by the Koch's postulates, which helps in the observation of its morphology by the electron microscopy. ${ }^{[34]}$ Explicit finding is by explicit subatomic tests on respiratory examples (bronchoalveolar lavage/endotracheal suctions and swabs of sputum/nasopharyngeal/throat). The viruses can also be found or identified through the examination of stool when it is extreme and from the blood of the patients. ${ }^{[35]}$ The clinical finding COVID-19 is based primarily on clinical indicators, disease histories, and some helper assessments, for example, nucleic acid detection, CT scans, immune screening technology and blood culture. ${ }^{[25]}$ At a research center, enhancement of the hereditary material separated from the salivation or bodily fluid example is through a real-time quantitative polymerase chain reaction (RT-qPCR) which includes the amalgamation of a twofold stranded DNA molecule from an RNA form. When the hereditary material is adequate, the quest is for those parts of the hereditary code of the $\mathrm{CoV}$ that are rationed. ${ }^{[36]}$ If the test outcome is certain, it is prescribed that the test is rehashed for confirmation. In patients with affirmed COVID-19 findings, the research center assessment ought to be rehashed to assess for viral leeway before being discharged from perception. ${ }^{[9]}$ Be that as it may, the person suffering or infected with the COVID-19 has the numerous types of clinical signs and symptoms which are fundamentally like viral pneumonia, dyspnea, fever, cough, and respiratory. In this way, helper assessments are important for the determination of COVID-19, similarly for disease history. ${ }^{[25]}$ RT-qPCR is no doubt having a great affinity towards the testing of this virus, but still, there is some conflict of results which states it to be having some false result too. Thus, the clinicians also suggest having the CT scan for this to identify the infected person. Also, if there is much more doubt or the patients are high on risk then both chest CT scan along with the RT-qPCR was performed on the person to confirm the status of the result. It allows for more accurate and precise data for the patients. ${ }^{[37]}$

\section{TREATMENT}

Since the first case was reported in December 2019, and as of now, we don't have any specific or particular drug, agent, or vaccine to fight against the COVID-19. [19] The typical standards are keeping up hydration and sustenance and controlling fever and cough. [35] The steady treatment, including oxygen treatment, preservation liquid administration, and the utilization of expansive range antimicrobial to cover optional bacterial contamination, stays to be the most significant administration methodology. ${ }^{[17]}$

Chloroquine phosphate, an old medication for the treatment of malaria, it appeared to have clear adequacy and worthy safety against COVID-19-related pneumonia in the first clinical trials directed at China. It shows antiviral exercises by meddling with the glycosylation of cell receptors through expanding endosomal $\mathrm{pH}$ required for virus/cell combination. ${ }^{[38]}$

The treatment with Hydroxychloroquine is fundamentally connected to the reduction of virus/vanishing in the patients of COVID-19. [39] The Hydroxychloroquine has a regulating impact on enacted invulnerable cells, and there is a decrease in the outflow of Toll-like receptors (TLRs) and TLR-mediated transduction, as well as diminishes the creation of interleukin6. ${ }^{[40]}$ It forestalls serious respiratory tract contaminations when administrated to patients enduring viral disease. Azithromycin added to hydroxychloroquine was essentially a synergistic impact of the mix and increasingly productive for virus elimination. ${ }^{[39]}$

Neuraminidase inhibitors (zanamivir, peramivir, oseltamivir, etc) ${ }^{[41]}$ which goes about as hindering the action of the viral neuraminidase chemical, keeping growing from the modulator 


\section{International Journal of Engineering Applied Sciences and Technology, 2020 \\ Vol. 5, Issue 1, ISSN No. 2455-2143, Pages 215-221 \\ Published Online May 2020 in IJEAST (http://www.ijeast.com)}

cell, viral dysfunction, and replication. ${ }^{\text {[42] }}$ There are other antiviral like protease inhibitors (Ritonavir /Lopinavir) which goes about as hindering protein cleavage of HIV-1 proteinase, which comes in unprotected germ cells. The other one is nucleotide analog prodrug (Remdesivir (GS-5734)) which goes about as meddling with virus post-passage and it is under test status. ${ }^{[43]}$ The synthetic guanosine nucleoside (Ribavirin) likewise been tried against the COVID-19 as it acts by meddling with the combination of viral mRNA (a wide range action several viruses of DNA and RNA). ${ }^{[44]}$ The nucleoside simple (Ganciclovir/Acyclovir/Penciclovir) additionally demonstrated a noteworthy action, yet at the same time, the craving pathway stays to set up. ${ }^{[45]}$

Tocilizumab is a recombinant monoclonal antibody that binds to the interleukin-6 (IL-6) receptor and prevents it from working. It is used in patients with COVID-19 levels that have elevated IL-6 levels; the specialist is being examined at the clinic. ${ }^{[46]}$ Favipiravir (T-705) which a nucleoside simple goes about as viral RNA polymerase inhibitor by following the replication of a toxic gene to forestall its proliferation, without influencing the combination of cell RNA or DNA, the operator is under investigational status for COVID-19. [47] Alongside these virally focused on inhibitors specialists, there is some more treatment that has been followed in the treatment of this disease like antibody and convalescent plasma as a potential therapy. ${ }^{[48]}$

\section{PREVENTION}

Since as of now there are no endorsed medicines for this disease, prevention is critical. [35] The COVID-19 said to transmit starting with one then onto the next individual, so it is important to totally intrude on human-to-human transmission. [49] The better way is the isolation of affirmed or suspected cases in the home is suggested. ${ }^{[25]}$ Isolation is a division of the sick population from the persons who are not affected by it and at the same time, the rest of the people must be in quarantine, which is movement limitation, and the one who came under the contact of corona patients or exposure zone. Additionally, we ought to follow the social distancing, which is intended to lessen communications between individuals in a more extensive network, in which people might be irresistible have not yet been distinguished thus not detached. As diseases transmitted by respiratory beads require certain vicinity of individuals, the social separating of people will decrease transmission. ${ }^{[49]}$ Another method to control the spread is to avoid the diligence of coronaviruses on inanimate surfaces because of various kinds of materials it can stay irresistible for 2 hours as long as 9 days. In this manner, it required the inactivation of it with biocidal operators like benzalkonium chloride, sodium hypochlorite, alcohols, or hydrogen peroxide, which are utilized worldwide for sterilization. ${ }^{[50]}$

The WHO and different associations have given the accompanying general proposals:
- Avoid close contact with subjects experiencing intense respiratory diseases.

- Wash your hands every frequently

- People with manifestations of intense airway route contamination should stay away, covering sneezes or coughs with clothes or tissues which are disposable and then wash your hands.

- Strengthen, specifically, in crisis medication divisions, the utilization of severe cleanliness measures for the anticipation and control of contaminations.

- Individuals that are immunocompromised ought to maintain a strategic distance from open social events. [9]

Healthcare workers caring for contaminated people ought to use the contact and airborne safeguards to incorporate PPE, for example, N95 or FFP3 masks, eye protection, outfits, and gloves to forestall transmission of the pathogen. ${ }^{[25]}$

\section{CONClusion}

Coronaviruses cause ailment going in seriousness from the regular cold to extreme respiratory disease and death. Coronavirus is non-sectioned wrapped positive-sense singlestrand RNA viruses, having a place with the Coronaviridae family. This novel coronavirus is to be believed to get spread from the bat and later on a human to human transmission. Individuals from this enormous group of viruses can cause respiratory, enteric, hepatic, and neurological disorders in various species, including camels, cattle, cats, and bats. There are various techniques to diagnose it like CT scan, RTqPCR and other. Since as of now there are no endorsed medicines for this disease, but still some of them show great affinities like Hydroxychloroquine, Neuraminidase inhibitors, protease inhibitors, analog prodrug, synthetic guanosine nucleoside, or Chloroquine phosphate and others. By following the basic hygiene fundamentals, we can protect ourselves from it and if there are any patients found with this virus must be taken to isolation center, and also the person who came under the contact of infected must be quarantined. Social distancing is one more to prevent the spread of this virus as well as the proper sanitization of the infected area or high-risk zone.

\section{REFERENCE}

[1] Wang C, Horby PW, Hayden FG, Gao GF. (2020). A novel coronavirus outbreak of global health concern. Lancet, Vol. 395, (pp.470-3).

[2] Coronavirus Outbreak. Available at: https://www.worldometers.info/coronavirus/. Accessed 17 April 2020.

[3] Liu Y, Gayle AA, Wilder-Smith A, Rocklov J. (2020). The reproductive number of COVID-19 is 


\section{International Journal of Engineering Applied Sciences and Technology, 2020 \\ Vol. 5, Issue 1, ISSN No. 2455-2143, Pages 215-221 \\ Published Online May 2020 in IJEAST (http://www.ijeast.com)}

higher compared to SARS coronavirus. J Travel Med, Vol. 27, No. 2, (pp. 1-6).

[4] Weiss SR, Leibowitz JL. (2011). Coronavirus pathogenesis. Adv Virus Res, Vol. 81, (pp.85-164).

[5] Zhu N, Zhang D, Wang W, Li X, Yang B, Song J, et al. (2020). A Novel Coronavirus from Patients with Pneumonia in China, 2019. N Engl J Med, Vol. 382, No. 8, (pp. 727-33).

[6] Richman DD, Whitley RJ, Hayden FG. (2017) Clinical Virology. 4th ed. Washington, DC: ASM Press; (pp.1243-65).

[7] World Health Organization. Statement on the second meeting of the International Health Regulations (2005) Emergency Committee regarding the outbreak of novel coronavirus (2019-nCoV). 2020. at https://www.who.int/news-room/detail/30-01-2020statement-onthe-second-meeting-of-the-internationalhealth-regulations-(2005)-emergencycommitteeregarding-the-outbreak-of-novel-coronavirus-(2019ncov). Published $31^{\text {th }}$ of January 2020.

[8] World Health Organization. WHO Director-General's remarks at the media briefing on $2019-\mathrm{nCoV}$ on $11^{\text {th }}$ of February 2020. At https://www.who.int/dg/speeches/detail/whodirectorgeneral-s-remarks-at-the-media-briefing-on-2019ncov-on-11-february-2020. Published $11^{\text {th }}$ of February 2020.

[9] Cascella M, Rajnik M, Cuomo A, Dulebohn SC, Napoli RD. (2020). Features, Evaluation and Treatment Coronavirus (COVID-19). StatPearls Publishing, (pp.1-14).

[10]Lu R, Zhao X, Li J, Niu P, Yang B, Wu H, et al. (2020). Genomic characterisation and epidemiology of 2019 novel coronavirus: implications for virus origins and receptor binding. The Lancet. Vol. 395, No. 10224, (pp.565-74).

[11]Chan JF TK, Tse H, Jin DY, Yuen KY. (2013) Interspecies transmission and emergence of novel viruses: lessons from bats and birds. Trends Microbiol, Vol. 10, (pp.544-5).

[12] Xu X, Chen P, Wang J, Feng J, Zhou H, Li X, et al. (2020). Evolution of the novel coronavirus from the ongoing Wuhan outbreak and modeling of its spike protein for risk of human transmission. Sci China Life Sci, Vol. 63, No. 3, (pp.457-60).

[13] Chen Y, Liu Q, Guo D. (2020). Emerging coronaviruses: Genome structure, replication, and pathogenesis. J Med Virol, Vol. 92, No. 4, (pp. 41823).

[14] Guo YR, Cao QD, Hong ZS, Tan YY, Chen SD, Jin $\mathrm{HJ}$, et al. (2020). The origin, transmission and clinical therapies on coronavirus disease 2019 (COVID-19) outbreak - an update on the status. Mil Med Res, Vol. 7, No. 11, (pp. 1-10).
[15] Li Q, Guan X, Wu P, Wang X, Zhou L, Tong Y, et al. (2020). Early Transmission Dynamics in Wuhan, China, of Novel Coronavirus-Infected Pneumonia. N Engl J Med, Vol. 382, No. 13, (pp. 1199-207).

[16] Wang JW, Tang FW. (2020). Updated understanding of the outbreak of 2019 novel coronavirus (2019$\mathrm{nCoV}$ ) in Wuhan, China. J Med Virol, Vol. 92, No. 4, (pp. 441-47).

[17] Huang CY, Wang X, Li L, Ren J, Zhao Y, et al. (2020). Clinical features of patients infected with 2019 novel coronavirus in Wuhan, China. Lancet, Vol. 395, No. 10223, (pp. 497-506).

[18] Lee N HD, Wu A, Chan P, Cameron P, Joynt GM, Ahuja A, Yung MY, et al. (2003). A major outbreak of severe acute respiratory syndrome in Hong Kong. N Engl J Med, Vol. 348, No. 20, (pp. 1986-94).

[19]Rothan HA, Byrareddy SN. (2020). The epidemiology and pathogenesis of coronavirus disease (COVID-19) outbreak. J Autoimmun, Vol. 109, No. 102433, (pp. 1-4).

[20] Carlos WG, Cruz CSD, Cao B, Pasnick S, Jamil S. (2020). Novel wuhan (2019-nCoV) coronavirus. Am J Respir Crit Care Med, Vol. 201, No. 4, (pp. 7-8).

[21] Wu P, Hao X, Lau EHY, Wong JY, Leung KSM, Wu JT, et al. (2020). Real-time tentative assessment of the epidemiological characteristics of novel coronavirus infections in Wuhan, China, as at 22 January 2020. Euro Surveill, Vol. 25, No. 3, (pp. 16).

[22] Chen H, Guo J, Wang C, Luo F, Yu X, Zhang W, et al. (2020). Clinical characteristics and intrauterine vertical transmission potential of COVID-19 infection in nine pregnant women: a retrospective review of medical records. The Lancet, Vol. 395, No. 10226, (pp. 809-15).

[23] Jaimes JA, Millet JK, Stout AE, Andre NM, Whittaker GR. (2020). A Tale of Two Viruses: The Distinct Spike Glycoproteins of Feline Coronaviruses. Viruses, Vol. 12, No. 83, (pp. 1-14).

[24] Wan Y, Shang J, Graham R, Baric RS, Li F. (2020). Receptor Recognition by the Novel Coronavirus from Wuhan: an Analysis Based on Decade-Long Structural Studies of SARS Coronavirus. J Virol, Vol. 94, No. 7, (pp. 1-9).

[25] Li X, Geng M, Peng Y, Meng L, Lu S. (2020). Molecular immune pathogenesis and diagnosis of COVID-19. J Pharm Anal, Vol. 10, (pp. 1-7).

[26] Jia HP, Look DC, Shi L, Hickey M, Pewe L, Netland J, et al. (2005). ACE2 receptor expression and severe acute respiratory syndrome coronavirus infection depend on differentiation of human airway epithelia. J Virol, Vol. 79, No. 23, (pp. 14614-21).

[27]Zhou P, Yang XL, Wang XG, Hu B, Zhang L, Zhang $\mathrm{W}$, et al. (2020). A pneumonia outbreak associated 


\section{International Journal of Engineering Applied Sciences and Technology, 2020 \\ Vol. 5, Issue 1, ISSN No. 2455-2143, Pages 215-221 \\ Published Online May 2020 in IJEAST (http://www.ijeast.com)}

with a new coronavirus of probable bat origin. Nature, Vol. 579, No. 7798, (pp. 270-3).

[28] Tortorici MA, Veesler D. (2019). Structural insights into coronavirus entry. Adv Virus Res, Vol. 105, (pp. 93-116).

[29] de Wilde AH, Snijder EJ, Kikkert M, van Hemert MJ. (2018). Host factors in coronavirus replication. Curr Top Microbiol Immunol, Vol. 419, (pp. 1-42).

[30] Sawicki SG, Sawicki DL. (2005). Coronavirus transcription: a perspective. Curr Top Microbiol Immunol, Vol. 287, (pp. 31-55).

[31] Hussain S, Pan J, Chen Y, Yang Y, Xu J, Peng Y, et al. (2005). Identification of novel subgenomic RNAs and noncanonical transcription initiation signals of severe acute respiratory syndrome coronavirus. J Virol, Vol. 79, No. 9, (pp. 5288-95).

[32] Perrier A, Bonnin A, Desmarets L, Danneels A, Goffard A, Rouille Y, et al. (2019). The C-terminal domain of the MERS coronavirus $\mathrm{M}$ protein contains a trans-Golgi network localization signal. J Biol Chem, Vol. 294, No. 39, (pp. 14406-21).

[33] Letko M, Marzi A, Munster V. (2020). Functional assessment of cell entry and receptor usage for SARS-CoV-2 and other lineage B betacoronaviruses. Nat Microbiol. Vol. 5, No. 4, (pp. 562-9).

[34] Lu H, Stratton CW, Tang YW. (2020). Outbreak of pneumonia of unknown etiology in Wuhan, China: the mystery and the miracle. J Med Virol, Vol. 92, No. 4, (pp. 401-2).

[35] Singhal T. (2020). A Review of Coronavirus Disease2019 (COVID-19). Indian J Pediatr, Vol. 87, No. 4, (pp. 281-6).

[36] Corman VM, Landt O, Kaiser M, Molenkamp R, Meijer A, Chu DK, et al. (2020). Detection of 2019 novel coronavirus (2019-nCoV) by real-time RTPCR. Euro Surveill, Vol. 25, No. 3, (pp. 1-8).

[37] Pan Y, Guan H, Zhou S, Wang Y, Li Q, Zhu T, et al. (2020). Initial CT findings and temporal changes in patients with the novel coronavirus pneumonia (2019-nCoV): a study of 63 patients in Wuhan, China. Eur Radiol, (pp. 1-4).

[38] Gao J, Tian Z, Yang X. (2020). Breakthrough: Chloroquine phosphate has shown apparent efficacy in treatment of COVID-19 associated pneumonia in clinical studies. Biosci Trends, Vol. 14, No. 1, (pp. 72-3).

[39] Gautret P, Lagier JC, Parola P, Hoang VT, Meddeb L, Mailhe M, et al. (2020). Hydroxychloroquine and azithromycin as a treatment of COVID-19: results of an open-label non-randomized clinical trial. Int $\mathbf{J}$ Antimicrob Agents, Vol. 20, (pp. 1-12).

[40] Plantone D, Koudriavtseva T. (2018). Current and Future Use of Chloroquine and Hydroxychloroquine in Infectious, Immune, Neoplastic, and Neurological
Diseases: A Mini Review. Clin Drug Investig, Vol. 38, (pp. 653-71).

[41] McQuade B, Blair M. (2015). Influenza treatment with oseltamivir outside of labeled recommendations. Am J Health, Vol. 72, No. 2, (pp. 112-6).

[42] Jefferson T, Jones M, Doshi P, Spencer EA, Onakpoya I, Heneghan CJ. (2014). Oseltamivir for influenza in adults and children: systematic review of clinical study reports and summary of regulatory comments. BMJ, Vol. 348, (pp. 2545).

[43] Holshue ML, DeBolt C, Lindquist S, Lofy KH, Wiesman J, Bruce H, et al. (2020). First Case of 2019 Novel Coronavirus in the United States. N Engl J Med, Vol. 382, No. 10, (pp. 929-36).

[44] Arabi YM, Shalhoub S, Mandourah Y, Al-Hameed F, Al-Omari A, Al Qasim E, et al. (2019). Ribavirin and interferon therapy for critically ill patients with middle east respiratory syndrome: a multicenter observational study. Clin Infect Dis, Vol. 70, No. 9, (pp. 1837-44).

[45] Shiraki K. (2018). Antiviral drugs against alphaherpesvirus. Adv Exp Med Biol, Vol. 1045, (pp. 103-22).

[46] Biggioggero M. Crotti C. Becciolini A. Favalli EG. (2018). Tocilizumab in the treatment of rheumatoid arthritis: An evidence-based review and patient selection. Drug Des. Dev. Ther, Vol. 13, (pp. 57-70).

[47] Furuta Y, Gowen BB, Takahashi K, Shiraki K, Smee DF, Barnard DL. (2013). Favipiravir (T-705), a novel viral RNA polymerase inhibitor. Antivir Res, Vol. 100, No. 2, (pp. 446-54).

[48] Chen L, Xiong J, Bao L, Shi Y. (2020). Convalescent plasma as a potential therapy for COVID-19. The Lancet Infectious Diseases, Vol. 20, No. 4, (pp. 398400).

[49] Wilder-Smith A, Freedman DO. (2020). Isolation, quarantine, social distancing and community containment: pivotal role for old-style public health measures in the novel coronavirus (2019-nCoV) outbreak. J Travel Med, Vol. 27, No. 2, (pp. 1-6).

[50] Kampf G, Todt D, Pfaender S, Steinmann E. (2020). Persistence of coronaviruses on inanimate surfaces and their inactivation with biocidal agents. J Hosp Infect, Vol. 104, No. 3, (pp. 246-51). 